\title{
The BASE-Project - an open-source catalogue for earthquakes in Bavaria, Germany
}

\author{
F. Barnikel ${ }^{1}$ and E. Geiss ${ }^{2}$ \\ ${ }^{1}$ Geography Section, Department for Geo- and Environmental Sciences, University of Munich, Luisenstrasse 37, \\ 80333 Munich, Germany \\ ${ }^{2}$ Department of Geophysics, Bavarian Environment Agency, Lazarettstrasse 67, 80797 Munich, Germany
}

Received: 22 September 2008 - Revised: 30 October 2008 - Accepted: 31 October 2008 - Published: 11 December 2008

\begin{abstract}
The BASE-project collects all earthquakes which have been recorded in historical documents in Bavaria up to the installation of the first major seismograph in 1905. 27 crucial publications of the past two centuries have already been assessed and the reports, 1112 in total, have been filed in a data base. Included are not only all events which have been recorded for Bavaria itself, but also events which have been felt and recorded in Bavaria, but may have taken place in neighbouring countries. The data base will be published on the internet. In a second step public users of the data are encouraged to take part in the improvement and completion of the data base. This especially aims at local historians, librarians etc. who can contribute to the data base by adding information and data from local archives or documents, which would otherwise be virtually inaccessible for the public.
\end{abstract}

\section{The goal of BASE}

The onset of the 21st century has brought a new public awareness about natural hazards. Recent catastrophic events like the 2004 tsunami in Asia or the 2005 flooding of New Orleans have made it not only to the headlines in news publications around the globe but have also contributed to a more profound desire to accumulate knowledge about natural hazards among people all over the world. The Bavarian Geological Survey (now part of the Bavarian Environmental Office) is about to pay tribute to this by offering new tools to research and monitor hazardous events in Bavaria. One project to reach this goal was the BASE-project (Bavaria's Seismicity in Historical Documents).

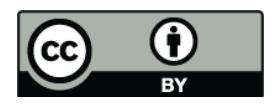

Correspondence to: F. Barnikel (mail@barnikel.de)
In a first step all data about earthquakes felt in Bavaria needed to be collected. This step was limited to already published data in 27 crucial publications over the past two centuries (Perrey, 1844; Boegner, 1847; Volger, 1857; Credner, 1884; Gümbel, 1889; Langenbeck, 1892; Günther, 1897; Günther, n.d.; Gümbel, 1898; Brunhuber, 1903; Reindl, 1903a, 1903b, 1905a, 1905b, 1907; Reindl, ; Günther and Reindl, 1904; Credner, 1907; Heritsch, 1908; Messerschmitt, 1908; Gießberger, 1922; Sieberg, 1940; Sponheuer, 1952; Schmedes, 1979; Leydecker and Brüning, 1988; Wolf and Wolf, 1989; Bachmann and Schmedes, 1993; Schmedes et al., 1993). The publications could be found in the Geophysical Observatory in Fürstenfeldbruck (jointly run by the Bavarian Geological Survey and the University of Munich), the Library of the Bavarian Geological Survey and the State Library of Bavaria in Munich. The data were filed in a specially designed data base, which was modified from the one successfully used in the HANG-project about natural hazards in the Alps (Barnikel, 2004). A second, future step will be the inclusion of (validated) contributions made by citizens all over Bavaria who share an interest in earthquakes and have access to local publications or documents which may have been denied wider distribution in journals or other scientific publications and are, therefore, largely unknown.

\section{Historical documents and natural hazards}

Since a thorough assessment of historical documents (the value of which has been proven many times, foremost in the field of hydrology, cf. Stedinger and Cohn, 1986; Alexandre, 1987; Baker, 1987) filed in the numerous archives all over the state of Bavaria would prove too time-consuming and costly by far (cf. Coeur et al., 1998 or Barnikel and Becht, 2004), a new way has to be found to gather as much relevant information as possible in a shorter period of time. Especially local archives, which have found to be among the most productive

Published by Copernicus Publications on behalf of the European Geosciences Union. 
and important sources for documents describing hazardous natural events from the 1800s and older (cf. Barnikel and Becht, 2003) cannot be screened by scientists alone. People with access to local documents, like librarians or historians, will be encouraged to contribute to the data base as a kind of open-source catalogue. Thus they may significantly enlarge our knowledge about "Bavarian" earthquakes in general.

We are well aware of the fact that the quoting of "original" texts is often unprecise or even faulty. Many of the written sources have already been shortened, translated, paraphrased or compiled, thus distorting the information of the underlying primary sources. On top of that, some compilations may include mistakes like wrong datings. Sometimes compilations are a mixture of reliable and questionable data (cf. e.g. Pfister, 1988 or Glade et al., 2001), as is especially the case with the "long" catalogues of earthquakes collected by Reindl (1903a, b), Gießberger (1922) or Sieberg (1940). The plausibility of the data can only be elicited by a thorough assessment of the data itself and a comparison of the data in question with established catalogues. In general, the co-operation of historians and geoscientists proves very valuable for the assessment of historical hazard data (see Coeur et al., 1998), even if the majority of the historical documents, which are needed to prolong the list of events into the past, only provides binominal data compared to the more valuable censored data of mostly younger documents (cf. Stedinger and Cohn, 1986).

As usual with historical data, several aspects regarding the quality of written sources need of course be kept in mind (cf. e.g. Pfister and Hächler, 1991; Coeur et al., 1998; Fliri, 1998; Pfister, 1999 or Glaser et al., 2002). The documents may differ greatly with regard to terminology, detail, educational background of the author etc. Many sources are not capable of providing all the data expected and needed for a thorough assessment of earthquakes. But the more different sources (or -later- archives) we include in our data base, the more precise our earthquake data will become. Excellent examples of the analysis of historical data are the publications of Galadini et al. (2001) about the Veronese earthquake of 1117 (data files numbers 1084, 1559 and 1779-1782 in BASE), the work of Mucciarelli and Stucchi (2001) about disaster scenarios or, for the general approach, e.g. Hammerl and Lenhardt 1997 and Gisler et al. (2004). An up-to-date overview on German historical approaches is given by Grünthal (2004).

\section{Historical earthquakes in Bavaria}

Germany's standard earthquake catalogue was first published by Leydecker in 1986 (in parts based on the catalogue published by Grünthal, for example in 1988) and issued on behalf of the Federal Institute for Geosciences and Natural Resources. It claimed full coverage for all quakes from intensity MSK-1964 IV (Sponheuer, 1965) upwards and listed about 1900 events with either their epicentres in Germany or with macroseismic effects on Germany, but originating in neighbouring countries. Within the past 20 years the catalogue has been enlarged and revised several times, the latest version can be found under http://www.bgr.bund.de/DE/Themen/Seismologie/ Erdbeben/historisch/historische__erdbeben__node.html (as well as the two following catalogues). Today it lists more than 2500 events relevant for Germany before 1906. Leydecker not only shaped the German earthquake catalogue, he also, together with his late colleague van Gils, issued the European earthquake catalogue with more than 8500 events (intensity IV and more) for the covered countries until 1906. The latest addition of interest is the earthquake catalogue for southeastern Europe (Shebalin et al., 1997) with approximately 2000 events before 1906, but with only limited relevance for Bavaria. Other important catalogues for earthquakes relevant for Bavaria are the Swiss catalogue (Swiss Seismological Service, 2002), the Austrian catalogue (Central Institute for Meteorology and Geodynamics, 2006) and the latest catalogue for central and northern Europe by Grünthal and Wahlström (2003).

Between all catalogues slight discrepancies can be found, most of them regarding the precise location of the epicentre, its coordinates, the intensity and the corresponding radius. Even the Bavarian earthquake catalogue, although based on the German catalogue, shows some minor differences to the German catalogue, since it has been gently modified by the former director of the Geophysical Observatory in Fürstenfeldbruck, Eberhard Schmedes, all through the 1980s and 90s (cf. Schmedes, 1979; Schmedes et al., 1993). BASE could not pay attention to the differences between these catalogues, although a future assimilation of all existing catalogues would be highly desirable.

The Bavarian Earthquake catalogue, published by the Bavarian State Agency for Environment and accessible online (http://www.erdbeben-in-bayern.de/), lists 24 events up to 1905 with epicentres in Bavaria. The earliest of these earthquakes dates back to 1390. Earthquakes with epicentres outside Bavaria were documented but not included in the official catalogue with the 26 November 1902 Tachov (Czech Republic) event as an exception. From 1905 onwards the earthquakes were measured by a new Wiechert-seismometre in Munich, which took the precision of the measurements to a new level. The BASE-project, therefore, only concentrated on events before 1906 and tried to establish an earthquake catalogue that, just like the German catalogue by Leydecker (1986ff.) does for Germany, also includes earthquakes with macroseismic relevance for Bavaria. Some major publications on historical earthquakes were analysed (of importance were foremost Gümbel, 1898; Reindl, 1903a, b, 1905a, b; Gießberger, 1922; Sieberg, 1940; Sponheuer, 1952, but also listings from adjoining German states or other countries as covered by Perrey, 1844; Boegner, 1847; Volger, 1857; Credner, 1884, 1907; Heritsch, 1908). The data was then collected in a data base, which had already been successfully 


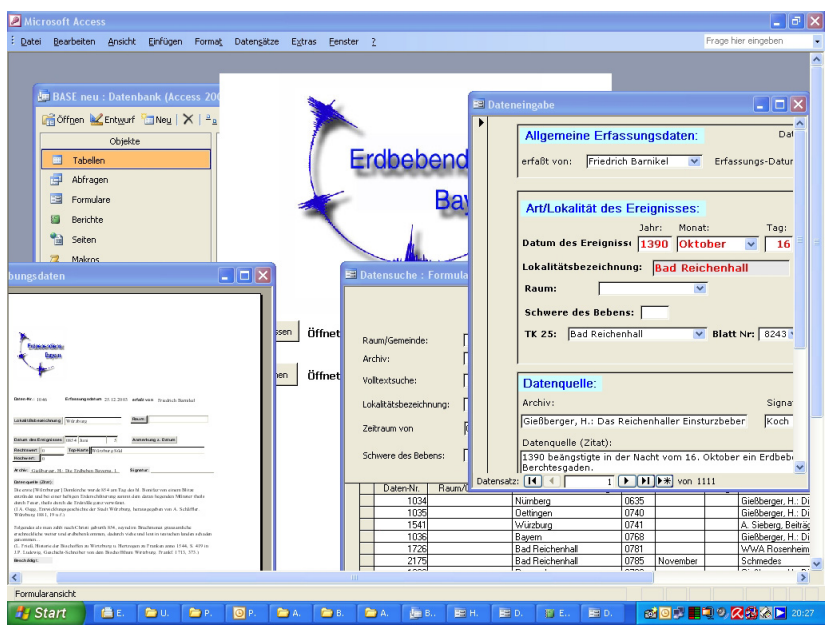

Fig. 1. Screenshot from the BASE data base showing the 1390 event in Bad Reichenhall.

used in another project on historical natural hazards, the HANG-project (Fig. 1).

Of special importance in this context, when working with historical written sources, is always the exact quotation of the written texts to ensure accessibility for later evaluations. BASE links the data on the event to other researched material, like pictures or maps. The data was then compared with the data in the German and European catalogues and, if necessary, adjusted (with regards to time, coordinates etc.). Important for the data files are descriptions of the impact an earthquake had on the society. The more details about damages or destructions we get, the more accurate our intensity estimations will later become. Therefore, all the data have been graded after the new EMS-98-Intensity-Scale (Grünthal, 1998), which allows a direct comparison of data from different centuries and of data from different documentary sources.

\section{Data from the BASE-project}

Some examples of historic written data may illustrate the particular problems and chances of working with this kind of sources in the BASE-project: "In the year 740 AD the Earth trembled so much in the Swabian Countries for almost a year that many monasteries and churches collapsed" (after Gießberger (1922), data sheet BASE-DB 1035). This text was found in a manuscript from 1723, therefore at least a second-hand source. Even if authors often used to simply copy older texts without changing them, a description of an earthquake almost a thousand years later is highly problematic (see Barnikel 2004, who deals at length with this topic). The nature of the information is also doubtful. The destruction of numerous churches and monasteries (some of them certainly wooden structures as were common in these times)

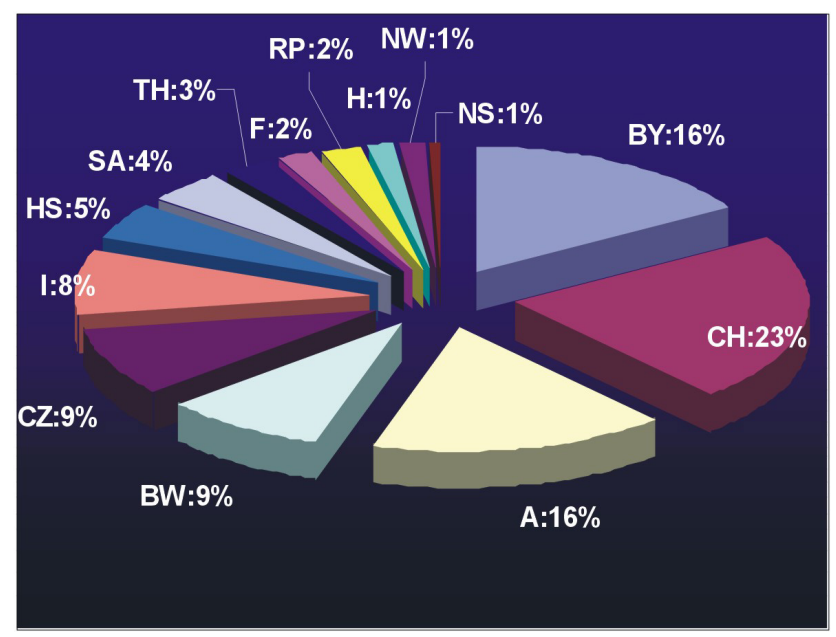

Fig. 2. Distribution of all events with known epicentres felt in Bavaria up to 1905 (BASE-project). Abbreviations: A = Austria, $\mathrm{CH}=$ Switzerland, $\mathrm{CZ}=$ Czech Republic, TH/S = former GDR, I = Italy, BW = German State of Baden-Württemberg, F = France, $\mathrm{RP}=$ German State of Rhineland-Palatine, $\mathrm{HS}=$ German State of Hesse, NP = German State of Northrhine-Westphalia.

sounds improbable. In addition to that, no other known source recorded that many devastating earthquakes in that year in Bavaria. The validity of this source, as a result, remains very poor.

Several sources were found for a suspected earthquake in 841 AD in Würzburg (after Boegner, 1847; Gießberger, 1922; Sieberg, 1940, BASE-DB 1044, the mentioned sources date back to e.g. $1578,1644,1692$ and 1756 respectively): "AD 841 an earthquake hit the town of Würzburg about twenty times and with it came terrible hail and a great storm", depicting the ancient belief that earthquakes were connected to atmospheric events. Judging from the text the event in question sounds more like a heavy storm which shook the buildings and inhabitants of Würzburg and is nowadays considered to be a fake. These "original" sources, used in the secondary sources exploited by the BASE-project, are of course hardly precise and valid, since they cannot be considered as contemporary (real contemporary sources being very rare and far between). Often sources like these make use of data already written down in older documents, thus only quoting other sources and thereby adding "new" evidence where there is none (cf. the exemplary analysis of a series of earthquakes in southern Germany found to be fakes by Grünthal and Fischer, 2001), or just mix up the dates, as is the case with earthquakes listed after either the Julian or the Gregorian calendar (as for example Grünthal and Wahlström (2003) point out).

Much more precise and valid in general are understandably younger documents, one example being an earthquake in 1889: "On 22 February, 2 o' clock and 40 min in the afternoon, a heavy blow sounded, which was accompanied by 


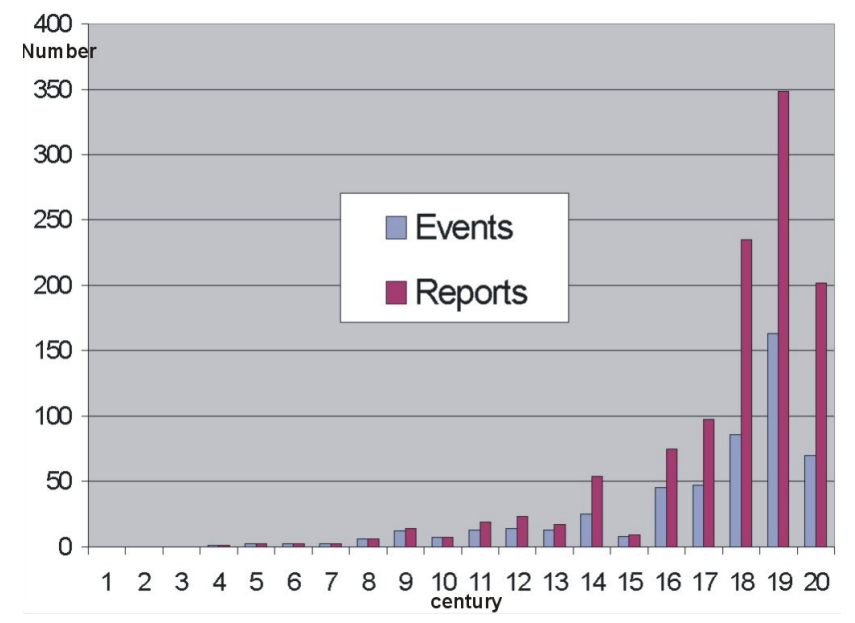

Fig. 3. Events recorded by BASE and corresponding reports over the centuries. Note that several reports may refer to the same event. The 20th century ends in 1905 .

a short rolling sub-surface, so that the windows clattered in many houses. This blow seemed to move from $\mathrm{W}$ to $\mathrm{E}$. In the lower part of town the same was felt so heavily that the inhabitants of the surrounding streets ran terrified onto the streets." This information appears not only much more reliable, it is also very precise in terms of date, time, place, process and effect. It is especially this kind of source we need to specify an earthquake (BASE-DB 1689).

The BASE-project was able to collect a total of 516 events which were felt and, consequently, recorded in Bavaria. Astonishing enough is the fact that about $76 \%$ of these events could not be linked to a specific date or place from the earthquake catalogues of the surrounding areas (the European earthquake catalogue by van Gils and Leydecker, 1991 or the German earthquake catalogue by Leydecker, 1986ff.), although quite a few quakes must be considered fakes, especially when just mentioned by a few (or only one) sources. Only 122 earthquake epicentres in addition to the 24 events already listed in the Bavarian earthquake catalogue could be specified (Fig. 2). Most of these events took place in either Switzerland (23\%) or Austria (16\%), just under 10\% in the German state of Baden-Württemberg, the Czech Republic or Italy respectively. The large number of uncertain epicentres for earthquakes felt in Bavaria is nevertheless puzzling, but so is the fact that both, the German and the European catalogue, list a significant different number of German quakes with the same intensity span for the time period up to 1905 . The European catalogue mentions 1019 events in Germany before 1906, the German catalogue 1821. (As long as there are such grave differences between the catalogues, every user is forced to establish his own catalogue as we do for Bavaria.)

The old Bavarian earthquake catalogue lists four events from the 14th until the 17th century, the oldest one being the 1390 event in Bad Reichenhall. BASE adds 72 events

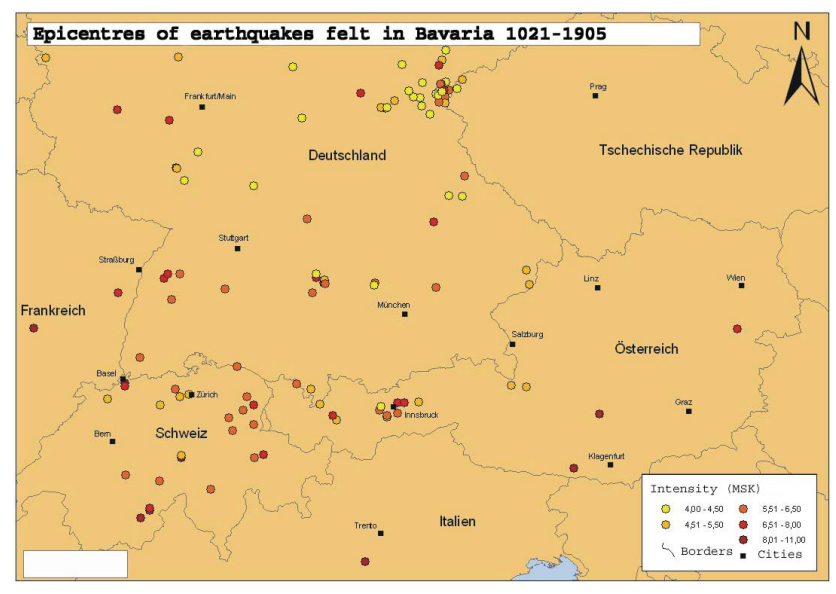

Fig. 4. Map of selected epicentres of earthquakes felt in Bavaria with a intensity of IV or more from 1021 to 1905 (BASE-project).

from the 4th century until the 17th century, the oldest one being a (questionable) quake recorded in Memmingen in 369 AD. The past few centuries are of course much better represented in the data base than the older ones (cf. Fig. 3). The renaissance of natural sciences after the 1500 s led to a more profound occupation with natural hazards. More people noted earthquakes and reported them. As a result we have more detailed information about quakes for the past few centuries than for the time before 1500. More than half of all events filed in the BASE-catalogue date back to the 18th and 19th centuries (86 and 163 events respectively), whereas the 10 th and 15 th centuries are astonishingly only sparsely represented.

The next interesting finding is the difference of the geographical distribution of the earthquakes before 1905 and after. Before 1905 most earthquakes felt in Bavaria took place in either the Alps or the northern fringe of the Bohemian Forest. But a surprisingly high number of events happened all over central Europe with no apparent connection to the more active seismic regions (Fig. 4). After 1905 we find quite a different picture, which obviously is connected to the installation of seismological stations in Bavaria, which were able to record also smaller earthquakes, "invisible" in the past. A large number of events was recorded for the Ries crater around Nördlingen (Fig. 5), although most epicentres are still found in the Alps or the northern Bohemian Forest.

\section{Discussion}

As a result, data from the BASE-project are useful with regard to several aspects:

- The data is compiled in a catalogue which can be accessed by every user through the internet. It is not only a valuable tool for specialists, it also helps the public understand geodynamics better. 


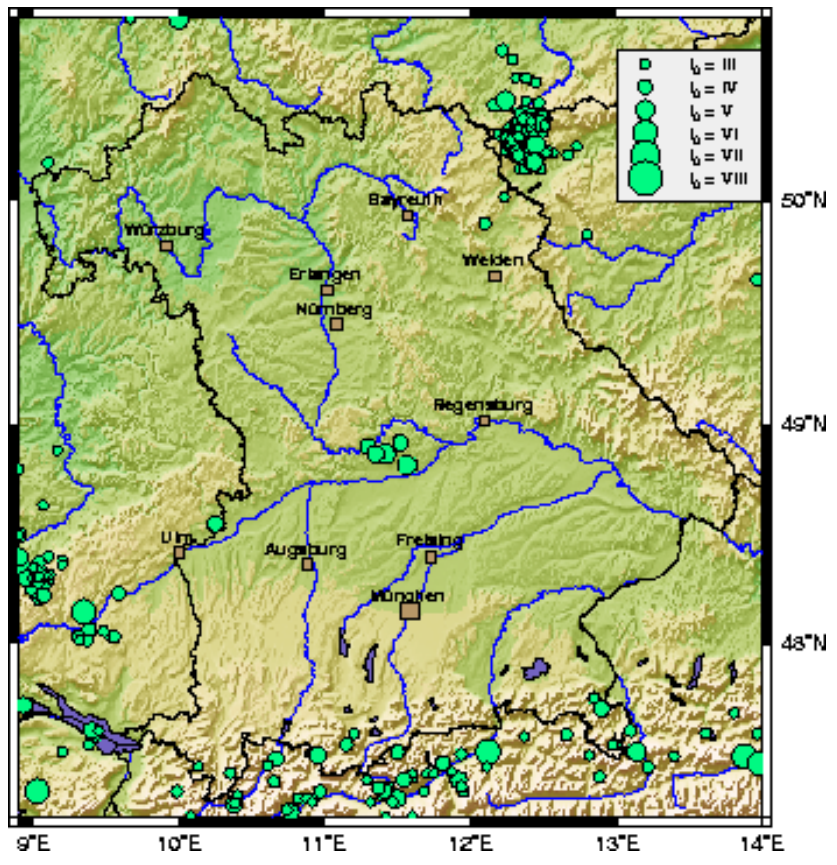

Fig. 5. Map of all recorded earthquakes in Bavaria between 1900 and 1999. Source: www.erdbebendienst.de.

- The catalogue will be enlarged and improved by citizens, thus including more man-power in scientific research and showing the public that everybody can contribute to the betterment of science and society, as an open-source project it will be a kind of Web 2.0-try to link science and public. (Figure 6 shows the distribution of all locations in Bavaria, which have reported earthquakes so far.)

- The data will help us to calibrate existing catalogues, especially the Bavarian catalogue, and should serve as a model for the calibration of other existing catalogues.

- The list of known earthquakes will be prolonged significantly and so provide a basis for future modelling.

The figure of unknown earthquake-epicentres remains a problem that needs to be solved. The inclusion of data from local archives is, consequently, of utmost importance. The future presentation of the BASE-DB on the web (www. erdbeben-in-bayern.de) is an important step to reach this goal and serves as an example for other catalogues. The inclusion of the original text sources is crucial in this respect, because it allows later adjustment and validation. But a future assimilation of the existing catalogues from the different European countries will also be important. The BASEproject will, in addition to that, collect written data for events after 1905 in a second step. A comparison between the written sources and instrumental data from the seismometre may prove useful for the calibration of older written data. Another step should be an examination, how reliability scales

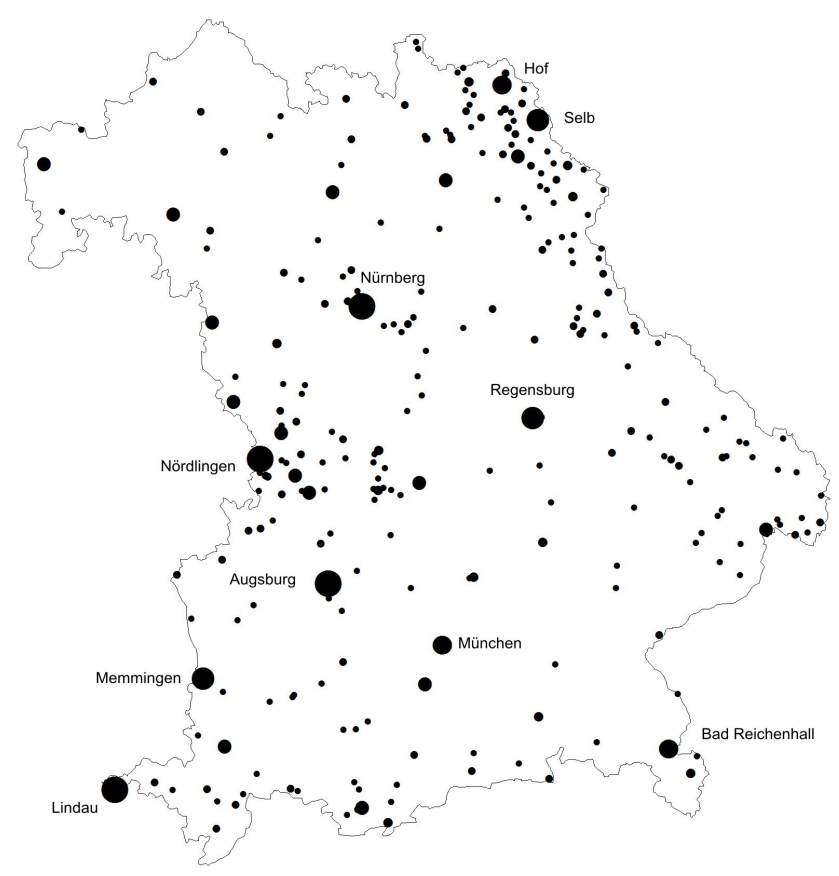

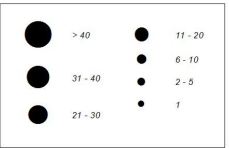

Fig. 6. Map of locations in Bavaria with number of reported earthquake events between 369 and 1905 (BASE-project).

(cf. Papadopoulos et al., 2000) could be used to classify the reliability of the historical earthquakes collected by BASE and the implementation of indicative magnitude values (cf. Sibol et al., 1987; Cavallini and Rebez, 1996 or Papazachos and Papaioannou, 1997) could be valuable. In the end the catalogue should then be ready to be used in further scientific studies about earthquakes in southern Germany.

Acknowledgements. The authors would like to thank the Bavarian Environment Agency for funding the project.

Edited by: M. Contadakis

Reviewed by: two anonymous referees 


\section{References}

Alexandre, P.: Le Climat en Europe au Moyen Age, Recherches d'histoire et de sciences sociales, 24, Paris, 1987.

Bachmann, C. and Schmedes, E.: Ein Schadensbeben in Neuhausen, Landkreis Landshut am 7. Februar 1822 - eine Zeitungsente, Z. angew. Geol., 39/2, 106-107, 1993.

Baker, V. R.: Paleoflood hydrology and extraordinary flood events, J. Hydrol., 96, 79-99, 1987.

Barnikel, F.: Analyse von Naturgefahren im Alpenraum anhand historischer Quellen am Beispiel der Untersuchungsgebiete Hindelang und Tegernseer Tal, Bayern, Göttinger Geographische Abhandlungen 111, Göttingen, 2004.

Barnikel, F. and Becht, M.: A historical analysis of hazardous events in the Alps - the case of Hindelang (Bavaria, Germany), Nat. Hazards Earth Syst. Sci., 3, 625-635, 2003, http://www.nat-hazards-earth-syst-sci.net/3/625/2003/.

Barnikel, F. and Becht, M: Möglichkeiten einer Bewertung des regionalen Gefährdungs-potentials auf der Basis historischer Naturgefahrenforschungen, in: Geomorphologische und hydrologische Naturgefahren in Mitteleuropa, Zeitschrift für Geomorphologie N. F., editd by: Becht, M. and Damm, B., Supplement Band 135, 1-10, 2004.

Boegner, J.: Das Erdbeben und seine Erscheinungen - Nebst einer chronologischen Uebersicht der Erderschütterungen im mittleren Deutschland vom 8. Jahrhundert bis auf die neueste Zeit und ihres Zusammenhanges mit vulkanischen Erscheinungen in entfernten Län-dern, Frankfurt a.M., 1847.

Brunhuber, A.: Zwei Erdbeben im Gebiete der Oberpfalz, Berichte des naturwissen-schaftlichen Vereins zu Regensburg, Heft IX 1901/02, 1-14, 1903.

Cavallini, F. and Rebez, A.: Representing earthquake intensitymagnitude relationship with a nonlinear function, Bu. Seismol. Soc. Am., 86/1A, 73-78, 1996.

Central Institute for Meteorology and Geodynamics: Katalog des Österreichischen Erdbebendienstes der ZAMG, Wien, 2006.

Coeur, D., Lang, M., Naulet, R., Burnet, R., and Strazzeri, D.: Histoire et connaissance des phénomenes naturels extremes, Ingénieres-EAT, 15-26, 1998.

Credner, H.: Die erzgebirgisch-vogtländischen Erdbeben während der Jahre 1878 bis Anfang 1884, Zeitschrift für Naturwissenschaften, Band LVII, 1-29, 1884.

Credner, H.: Die Sächsischen Erdbeben während der Jahre 1904 bis 1906, Aus den Berichten der mathematisch-physischen Klasse der Königlich Sächsischen Gesellschaft der Wissenschaften zu Leipzig, LIX. Band, 333-355, 1907.

Fliri, F.: Naturchronik von Tirol, Innsbruck, 1998.

Galadini, F., Galli, P., Molin, D., and Ciurletti, G.: Searching for the source of the 1117 earthquake in northern Italy: A multidisciplinary approach, in: The Use of Historical Data in Natural Hazard Assessments, Advances in Natural and Technological Hazards Research 17, edited by: Glade, T., Albini, P., and Francés, F., Dordrecht, 3-27, 2001.

Gießberger, H.: Die Erdbeben Bayerns I. Teil., Abhandlungen der Bayer. Akad. der Wissenschaften Mathematisch-Physikalische Klasse XXIX/6, München, 1922.

Gisler, M., Fäh, D. and Kästli, P.: Historical Seismicity in Central Switzerland, Eclogae Geo. Helv., 97, 221-236, 2004.

Glade, T., Albini, P., and Francés, F.: The Use of Historical Data in Natural Hazard Assessments, Advances in Natural and Techno- logical Hazards Research, 17, Dordrecht, 2001.

Glaser, R., Jacobeit, J., Deutsch, M., and Stangl, H.: Hochwasser als historisches Phänomen, in: Rundgespräche der Kommission für Ökologie, Bd. 24, München, 15-30, 2002.

Grünthal, G.: Erdbebenkatalog des Territoriums der Deutschen Demokratischen Republik und angrenzender Gebiete von 823 bis 1984, Veröffentlichungen des Zentralinstituts für Physik der Erde, 99, Potsdam, 1988.

Grünthal, G.: European Macroseismic Scale 1998, Cahiers du Centre Européen du Géodynamique et de Séismologie, 15, Luxemburg, 1998.

Grünthal, G.: The history of historical earthquake research in Germany, Ann. Geophys.-Italy, 47(2/3), 631-643, 2004.

Grünthal, G. and Fischer, J.: Eine Serie irrtümlicher Schadenbeben im Gebiet zwischen Nördlingen und Neuburg an der Donau vom 15. bis zum 18. Jahrhundert, Mainzer naturwissenschaftliches Archiv, 39, 15-32, 2001.

Grünthal, G. and Wahlström, R.: An earthquake catalogue for central, northern and northwestern Europe based on $M_{W}$ magnitudes, Potsdam, 2003.

Gümbel, C. W.: Das Erdbeben vom 22. Februar 1889 in der Umgegend von Neuburg a.D., Aus den Sitzungsberichten der mathematisch-physikalischen Classe der k. bayer. Akad. der Wiss. 1889, Bd. XIX Heft I, 79-108, 1889.

Gümbel, C. W.: Ueber die in den letzten Jahren in Bayern wahrgenommenen Erdbeben, Aus den Sitzungsberichten der mathematisch-physikalischen Classe der k. bayer. Akad. der Wiss. XXVIII, München, 3-18, 1898.

Günther, S.: Münchener Erdbeben- und Prodigienliteratur in älterer Zeit, Jahrbuch für Münchener Geschichte IV, 15, 234-256, n.d.

Günther, S.: Das bayerisch-böhmische Erdbeben vom Jahre 1329, 17, Jahresbericht der Geographischen Gesellschaft für 1896/1897, 76-88, 1897.

Günther, S. and Reindl, J.: Seismologische Untersuchungen, Aus den Sitzungsberichten der mathematisch-physikalischen Klasse der Kgl. Bayer. Akademie der Wissenschaften Bd. XXXIII 1903 Heft IV, 631-671, 1904.

Hammerl, C. and Lenhardt, W.: Erdbeben in Österreich, Wien, 1997.

Heritsch, F.: Über das Mürztaler Erdbeben vom 1. Mai 1885, Mitteilungen der Erdbeben-Komission der Kaiserlichen Akademie der Wissenschaften in Wien, Neue Folge XXXII, Wien, 1908.

Langenbeck, R.: Die Erdbebenerscheinungen in der oberrheinischen Tiefebene und ihrer Umgebung, in: Geographische Abhandlungen aus den Reichslanden Elsass-Lothringen, edited by: Gerland, G., Stuttgart, 1-120, 1892.

Leydecker, G.: Erdbebenkatalog für die Bundesrepublik Deutschland mit Randgebieten für die Jahre 1000-1981, Geol. Jb., E36, Hannover, 1986.

Leydecker, G. and Brüning, H.J.: Ein vermeintliches Schadenbeben im Jahre 1046 im Raum Höxter und Holzminden in Norddeutschland - Über die Notwendigkeit des Studiums der Quellen historischer Erdbeben, Geol. Jb., E42, 119-125, 1988.

Messerschmitt, J. B.: Die Erdbeben in Bayern 1905 bis 1907, Die Erdbebenwarte, IV. Jahrgang, Laibach, 94-96, 1907.

Mucciarelli, M. and Stucchi, M.: Expeditious seismic damage scenarios based on intensity data from historical earthquakes, in: The Use of Historical Data in Natural Hazard Assessments, Advances in Natural and Technological Haz-ards Research 17, 
edited by: Glade, T., Albini, P., and Francés, F., Dordrecht, 8186, 2001.

Papadopoulos, G., Vassilopoulou, A., and Plessa, A.: Historical Earthquakes and Tsunamis in the Corinth Rift, Central Greece, Institute of Geodynamics, National Observatory of Athens, Publ. No. 12, Athens, 9-120, 2000.

Papazachos, C. and Papaioannou, C.: The macroseismic field of the Balkan area, J. Seismol., 1, 181-201, 1997.

Perrey, A.: Mémoire sur les Tremblements de Terre resentis en France, en Belgique et en Hollande, Bruxelles, 1844.

Pfister, C.: Klimageschichte der Schweiz 1525-1860, Academia Helvetica, 6, Bern, 1988.

Pfister, C.: Wetternachhersage, 500 Jahre Klimavariationen und Naturkatastrophen, Bern, 1999.

Pfister, C. and Hächler, S.: Überschwemmungskatastrophen im Schweizer Alpenraum seit dem Spätmittelalter, Würzburger Geographische Arbeiten, 80, 127-148, 1991.

Reindl, J.: Beiträge zur Erdbebenkunde von Bayern, Aus den Sitzungsberichten der mathematisch-physikalischen Klasse der Kgl. Bayer. Akademie der Wissenschaften, Bd. XXXIII 1903, Heft I, 171-203, 1903a.

Reindl, J.: Die Erdbeben der geschichtlichen Zeit im Königreiche Bayern, Die Erdbebenwarte, II. Jahrgang, Laibach, 235-243, 1903b.

Reindl, J.: Die Erdbeben Nordbayerns, Abhandlungen d. Naturh. Gesellsch. XV. Bd., H. 3, Nürnberg, 3-46, 1905 a.

Reindl, J.: Ergänzungen und Nachträge zu v. Gümbels Erdbebenkatalog, Aus den Sitzungsberichten der mathematischphysikalischen Klasse der Kgl. Bayer. Akademie der Wissenschaften XXXV/I, München, 31-68, 1905 b.

Reindl, J.: Die Erdbeben Bayerns im Jahre 1904, Die Erdbebenwarte, IV. Jahrgang, Laibach, 178-184, 1907.

Schmedes, E.: Die seismische Aktivität im Raum Bad Reichenhall, Geol. Jb., C22, 91-101, 1979.

Schmedes, E., Loibl, R., and Gebrande, H.: Ein Schadensbeben in Regensburg am 8. Februar 1062 - eine Fehlinterpretation historischer Quellen, Z. angew. Geol., 39/2, 103-105, 1993.
Shebalin, N. V., Leydecker, G., Mokrushina, N. G., Tatevossian, R. E., Erteleva, O. O., and Vassiliev, V. Y.: Earthquake Catalogue for Central and Southeastern Europe 342 BC-1990 AD, Final Report to Contract ETNU-CT 93-0087, 1997.

Sibol, M., Bollinger, G., and Birch, J.: Estimation of magnitudes in central and eastern North America using intensity and felt area, B. Seismol. Soc. Am., 77/5, 1635-1654, 1987.

Sieberg, A.: Beiträge zum Erdbebenkatalog Deutschlands und angrenzender Gebiete für die Jahre 1758 bis 1799, Mitteilungen des Deutschen Reichs-Erdbebendienstes 2, Berlin, 1940.

Sponheuer, W.: Erdbebenkatalog Deutschlands und der angrenzenden Gebiete für die Jahre 1800 bis 1899, Deutsche Akademie der Wissenschaften, Mitteilungen des Deutschen Erdbebendienstes, 3, Berlin, 1952.

Sponheuer, W.: Bericht über die Weiterentwicklung der seismischen Skala, Veröffentlichungen des Institutes für Geodynamik, 8, Berlin, 1965.

Stedinger, J. R. and Cohn, T. A.: Flood frequency analysis with historical and paleoflood information, Water Resour. Res., 22/5, 785-793, 1986.

Swiss Seismological Service: ECOS - Earthquake Catalog of Switzerland, ECOS Report to PEGASOS, Version 31.3.2002, Zürich, 2002.

Van Gils, J. M. and Leydecker, G.: Catalogue of European earthquakes with intensities higher than 4, Commission of the European Communities, nuclear science and technology, Brussels, 1991.

Volger, O.: Untersuchungen über das Phänomen der Erdbeben in der Schweiz, Erster Theil: Chronik der Erdbeben in der Schweiz, Gotha, 1857.

Wolf, P. and Wolf, H.: Das Erdbeben in Regensburg von 1062 Wirklichkeit oder wis-senschaftliches Phantom?, Die Oberpfalz, 77. Jahrg., Heft 2, 35-43, 1989 